\title{
WEED PROBLEMS OF THE BAY OF PLENTY
}

\author{
By A. V. ALLO, Department of Agriculture, Tauranga
}

For the purpose of this paper the Bay of Plenty has been defined as the area of land included in the Tauranga, Whakatane, and Opotiki Counties. It consists of a narrow coastal strip extending from Athenree, near Katikati, in the north to Cape Runaway in the south-east, and is bounded inland by low ranges of hills rising up to $1,500 \mathrm{ft}$. Topography varies from easy rolling to hilly, with two large areas of swamp, one centred on Te Puke and the other, the Rangitaiki Plains, near Whakatane.

The climate is subtropical, with an annual rainfall ranging from 50 in. near the coast to over 80 in. on the hilly inland country. Dry summers and autumns are not uncommon. Soils over most of the area are derived from a series of volcanic ash showers. They are typically sandy in texture, free draining, liable to droughtiness, and are difficult to consolidate after they have been cultivated. They are very low in natural fertility, phosphate levels on virgin country being extremely low, while many of them were deficient in cobalt. Because of their light texture they are readily invaded by weeds.

The swamp soils are dominantly peaty loams, consisting of volcanic ash alluvium overlying peat. Though naturally higher in fertility than the rolling country, these swamp soils still require applications of fertiliser before they will produce satisfactorily.

In the early days of European settlement much of the coastal land of the Bay of Plenty was covered by bracken fern (Pteridium esculentum) and scrub, while the higher hills were still largely clothed in forest. The swamps had a natural cover of flax (Phormium tenax), manuka (Leptospermum scoparium), raupo (Typha angustifolia), cabbage trees (Cordyline australis), and rushes (Juncus spp.).

The first land to be developed was the easy rolling coastal country, where large areas of fern and scrub were burnt and sown to grass. No artificial fertilisers were used, and the low natural fertility of the land meant that these early pastures rapidly reverted to weeds, with only the poorest grasses remaining in the sward. They were then ploughed and sown down into a crop, usually maize or brassicas, after which they were regrassed. Early pastures in the Bay of Plenty were thus dominantly browntop (Agrostis tenuis), danthonia (Danthonia pilosa), Paspalum dilatatum, Indian doub (Cynodon dactylon), Yorkshire fog (Holcus lanatus), and weeds, with little or no clovers. Ragwort (Senecio jacobaea) became firmly established at the turn of the century and spread rapidly throughout the whole area. Control of this weed was extremely difficult, as no suitable chemicals were available and sheep could not be used because of the prevailing cobalt deficiency over much of the country. Gorse (Ulex europaeus) and blackberry (Rubus spp.) also started to become established over this period, gorse being sown for sheep feed on a number of properties.

Just before the First World War a few farmers began to use phosphatic fertilisers, mostly superphosphate, and the usage of this material increased rapidly in the $1920 \mathrm{~s}$. There was an immediate improvement in the quality of pastures, an improvement that was hastened when certified pasture seeds were introduced into the area in the 1930s. The introduction of cobalt in 1935 saw bush sickness brought under control, and the agricultural development of the Bay of Plenty really begin. In 1945 it was demonstrated that large areas of pasture lands needed potash, and the use of this fertiliser resulted in still further pasture improvement. Finally, an increasing usage of insecticides, and particularly of DDT superphosphate, has worked wonders in keeping grass-grub under control.

At this stage you may well be asking what has all this got to do with the weed problem of the Bay of Plenty. In point of fact, it is essential to have some knowledge of the farming development of this district in order to appreciate how some of our major weed problems originated. 
The type of farming characteristic of the early days of settlement, with its succession of crops and low-producing pastures, has been responsible for many of the weed problems that the modern farmer has to face. For instance, large portions of the Tauranga County are infested with Indian doub, a serious problem in cultivated land. Seed of this grass was sown in the early days, as it was one of the few pasture species capable of growing under the prevailing low-fertility conditions. The same could be said for browntop, while ragwort would never have been so serious a problem had not bush sickness prevented sheep from being run over much of the Bay. Thus it can be seen that the weed problems of today have been, at least to some extent, inherited.

Let us now consider the weeds that are associated with some of the major classes of country found in the Bay of Plenty. For ease of reference the following classes of land will be discussed.

1. Newly developed country.

2. Low-fertility pastures and open swards.

3. High-fertility established pastures.

4. The swamp country.

5. Cropping and horticultural areas.

\section{WEEDS ASSOCIATED WITH LAND DEVELOPMENT}

Because methods used in land development largely determine the future weed population of a block of country, it is proposed to devote a fair amount of time to this topic. There are four major classes of vegetation on undeveloped volcanic ash country of the Bay of Plenty.

(a) Native bush.

(b) Fern or manuka scrub or a mixture of both.

(c) Fern or manuka plus gorse.

(d) Hakea scrub (Hakea saligna).

To the present most of the land developed out of bush has had the bush cut and burnt and has been surface sown. Later easier areas may be logged up and stumped and sown to permanent pasture after a crop.

After the initial burn and grassing down the area usually becomes invaded with ragwort, Australian fireweed (Erechtites atkinsoniae), fleabane (Erigeron canadensis), and inkweed (Phytolacca octandra), while sorrel (Rumex acetosella), foxglove (Digitalis purpurea), and cudweed (Gnaphalium luteo-album) are also usually present. If adequate phosphates have been applied and the area is fenced up tightly so that stock can be crowded on to it, these weeds can be kept under control and a satisfactory sward is developed. Where fertility is not built up or insufficient stock are available these weeds will thrive and a poor sward will result. Thus weed control in the initial development of bush burn country is largely dependent on adequate phosphatic topdressing and stocking. A high standard of farming skill is required to hold this country, for when it starts to go back it reverts very rapidly to second growth, wineberry (Aristotelia serrata), fern, and such weeds. When this occurs it is costly to rehabilitate.

There are two different methods used in the development of bracken fern and manuka scrub country after the initial burn. One involves cultivating the land to work up a seedbed before sowing the grass seed, while the other consists of sowing the szed after the burn directly on to the ash.

If the land is cultivated after the burn, it is essential that the seedbed be well consolidated. If the seed is sown on loose soil, establishment of the pasture species is usually poor, particularly that of the clovers. The sward is thin and open, dries out readily in a dry summer, and is readily invaded with weeds, the worst of which are ragwort and sorrel. Other weeds found in such circumstances may be flatweeds (Hypochaeris radicata, Crepis capillaris, Leontodon leysseri), cudweed, possibly Australian fireweed, and fleabane. Because the sward is thin and weak, there is insufficient herbage to run heavy rates of stocking, so that weed control is all the more difficult. It only needs an attack of grass-grub to kill most of the remaining 
pasture grasses and sward deterioration is complete. In other words, cultivation of fern and scrub country should be approached with caution unless adequate facilities are available to permit thorough consolidation of the seedbed.

On the other hand, surface sowing after the burn does not destroy the natural consolidation of the soil, and there is usually a speedier and better establishment of the sward. Money saved in cultivation can be spent on more fertiliser and closer subdivision so that weed control is simplified.

Again, the weed population of newly developed fern and manuka country is influenced by the fertiliser treatment it received. This class of country is extremely low in available phosphate, and heavy initial dressings of phosphate are required if a rapid establishment of pasture is to be obtained. Weed control is greatly simplified if this is done.

The quality of seed sown is important. Many Bay of Plenty farmers in the past sowed "cheap" seed on their newly developed country, and many of our weed problems can be traced to this source. I would instance the introduction of winged (Carduus tenuiflorus) and nodding (C. nutans) thistle to the district as a case in point.

The weed population of newly sown fern country is also influenced by the closeness of the subdivision. Control of fern and manuka regrowth is dependent on heavy per-acre stocking for short periods, and inadequate subdivision permits these weeds to come away again.

To sum up one might say that the development of fern and manuka country poses no serious problems of weed control provided good-quality seed is sown on a firm seedbed well supplied with phosphate, and provided fencing is adequate to permit mob stocking for short periods.

The development of gorse country has always been a problem in the Bay of Plenty, particularly in the Tauranga County, where there are quite extensive areas of this weed. It has been established that even drastic cultivation may not eliminate the possibility of seedling growth in a newly sown sward, even if one or two crops of turnips are grown before the area is sown into pasture.

Other farmers have burnt the gorse after crushing and deep ploughed with a long-mouldboard semi-swamp plough, carting off the gorse roots after the ploughing. The land has then been worked down to a seedbed usually after a winter fallow, and sown down to grass in spring with a mixture containing a heavy seeding of cowgrass. The area is cut for hay or silage the following autumn, many of the gorse seedlings being killed when the crop is cut. This method of gorse country development, though slow and expensive, has proved very successful in controlling gorse.

Another method of developing gorse country is to burn the area. After the burn a strong growth of bracken fern will come away with the gorse seedlings and regrowths. After two years the area is burnt again and sown down with a heavy dressing of phosphate on the ash. The second burn will clean up most of the sticks that were left after the first burn, and will also kill much of the remaining gorse. Once the area is sown it is heavily stocked with sheep, which will keep the gorse seedlings under control. The final clean up of any remaining gorse can be achieved by spraying. This method of gorse country development is slow, but it has the advantage of cheapness, and is worthy of consideration on country that is too steep for a wheel tractor.

Up to the present the control of gorse in an existing pasture has been obtained either with sheep (seedling gorse), by the mower, or by the use of 2,4,5-T. Hormone weedicides have been applied as a spot treatment, by boom, or from the air. In all cases some clover damage has followed spray application, this being particularly severe after boom or aerial applications, particularly on young pastures. The introduction of the rotary cutter has given very promising results in gorse control on wheel tractor country and the use of this machine may possibly become more extensive in the future.

A few areas of the Bay of Plenty are covered in hakea scrub, ranging in height from 4 to $16 \mathrm{ft}$. This country is being developed either by crushing, burning and discing, or by burning the standing hakea during a hot 
dry summer, leaving it for two years and following up with a second burn and sowing on the ash. This last method is cheaper and again is to be preferred on steeper country.

There are a few more problem weeds found on some areas of newly developed country. Chief of these are broom (Cytisus monspessulanus) scotch broom (C. scoparius), and lupins (Lupinus arboreus). They frequently show up after a fern or scrub burn, and are controlled either with hormone weedicides or the rotary cutter. Scotch thistles (Cirsium lanceolatum) often appear during the early stages of land development, and though they can readily be controlled by hormone weedicides, in practice they are usually untouched, to be a problem for several years.

Under extremely low-fertility conditions, especially on shallower highcountry soils, spanish heath (Erica lusitanica) may become a problem; it can be controlled by topdressing and stocking, and also, if necessary, by hormone weedicides. Another weed that may invade the poorer faces is tauhinu (Pomaderris phylicaefolia). It can be controlled with 2,4,5-T.

\section{WEEDS OF LOW-FERTILITY ESTABLISHED PASTURES}

Ragwort is undoubtedly the worst in this category and it is not many years since this weed was widespread and thriving throughout the Bay of Plenty. It achieved its early dominance through lack of suitable topdressing, the open pastures encouraging its spread. The widespread incidence of bush sickness prevented sheep being used in its control; and it was not uncommon for dairyfarmers to be forced off their properties because they could not control the ragwort. The first chemicals to control ragwort were sodium chlorate and "Atlacide", but these proved to be palliatives rather than giving complete control. It was not until the advent of hormone weedicides in 1947 that the farmer on the holding too small to be an economic sheep unit was given the means to bring ragwort under control. Today the weed is largely under control though constant vigilance must be exercised by farmers to prevent its re-establishment on the hillier country. It is still a problem on unoccupied and newly developed country.

Indian doub another serious weed of low-fertility pastures, and in association with sodbound paspalum gives rise to a pasture type notable for almost complete lack of productive feed. Many pastures of this type are associated with potash deficiency, a condition that frequently arises after several years of farming, particularly on areas cut frequently for hay. Pastures of this type can frequently be transformed by applications of muriate of potash. Other common weeds associated with low fertility are scotch thistle, catsear, ribgrass (Plantago lanceolata), mouse-eared chickweed (Cerastium glomeratum), oxeye daisy (Chrysanthemum leucanthemum), sweet vernal (Anthoxanthum odoratum), musky storksbill (Erodium moschatum), browntop, cudweed, and tarweed (Odontites viscosa), while occasionally encountered are bathurst burr (Xanthium spinosum) and Vipers bugloss.

Ratstail (Sporobolus capensis) is a low-fertility weed grass which causes concern on the sunnier faces. Though it is claimed that it can be controlled by chemicals, I believe that good management will keep it under control very much more cheaply. It is frequently found on areas overstocked with sheep, and a build-up in fertility through increased topdressing, combined with heavy winter stocking with cattle and spring spelling, will work wonders in suppressing this weed.

Many of the thin and weedy pastures of the Bay of Plenty are the result not of low fertility, but of grass-grub damage, and excellent weed control has been obtained on some properties not by spraying with weedicides but by the application of insecticides.

Gorse and blackberry can also be found scattered over large areas of this lower-producing country, and are mainly being controlled by spraying with 2,4,5-T, though control by mechanical means may be cheaper and equally efficient in many cases.

Barberry (Berberis vulgaris) is a weed found on some areas of hill 
country and can be controlled by basal applications of 2,4,5-T and dieselene.

Other troublesome weeds of thin open pastures are chamomile daisy (Matricaria chamomilla) and stinking mayweed (Anthemis cotula). These have been declared noxious weeds in the Tauranga County, but are proving to be extremely difficult to control in pastures.

\section{WEEDS ON HIGH-FERTILITY ESTABLISHED PASTURES}

Most high-fertility areas in the Bay of Plenty are infested with docks (Rumex spp.) to some extent. All species of docks are to be found. Though excellent control of seedling docks in new pasture can be obtained with the new butyric weedicides, mature plants proved to be difficult to kill in established pasture. Probably the most efficient weedicide used is the amine salt of 2,4-D, but, even here, good results are not certain.

Very much the same position exists with Californian thistles. There appears to be no sure and certain control of this weed in established pastures, and very inconsistent results have followed spray applications. It may be that the most effective treatment is to spray at regular intervals with low rates of amine salt or ethyl ester of 2,4-D.

Common chickweed (Stellaria media) frequently causes concern in autumn-saved pasture, in which it tends to smother patches of grass and clover. Resistant to chemical weedicides, it is possibly best kept in check with the harrows after the area has been grazed off.

Other high-fertility weeds frequently encountered are capeweed (Cryptostemma calendulacea), hedge mustard (Sisymbrium officinale), marshmallow (Althaea officinalis), storksbill (Erodium cicutarium), and creeping mallow (Modiola caroliniana), though none of these could be termed problem weeds.

There are, however, two high-fertility weeds which are a definite problem in the district; of these, barley grass (Hordeum murinum), is easily the more serious. It is widespread throughout the Bay of Plenty. Up to the present only a few farmers have taken active steps to control barley grass, though very encouraging results have been obtained from the use of dalapon.

Twin cress (Coronopus didymus) is the other high-fertility problem weed in the Bay of Plenty. The presence of this annual in a pasture is liable to cause tainting of milk and cream when cows are grazed on the area, and a bad outbreak of cress in a district during spring can be very expensive to a dairy factory. Cress is a legacy from the days when cropping was so widespread and is found wherever the sward has been opened up. Though it is relatively easy to control, it will always give trouble on those farms where it is neglected through ignorance or indifference.

Though Kikuyu grass (Pennisetum clandestinum) is found in scattered localities, it does not spread rapidly and causes no economic loss.

\section{WEEDS OF THE SWAMP COUNTRY}

Much of the swamp country of the Bay of Plenty was developed somewhat later than the rolling country and the weed problems of these areas are largely associated with poor drainage and winter poaching.

Rushes, nearly all either J. effusus or $J$. polyanthemos, provide the greatest single weed problem of the swamps. They may be controlled through improved drainage and the use of hormone weedicides. Over recent years promising results have been obtained from the use of the rotary cutter. Other weeds of swamp pastures are buttercups (Ranunculus spp.) pennyroyal (Mentha pulegium), pennywort (Hydroctyle spp.), broadleaved plantain (Plantago major), sedges (Carex spp.), wood rush, and tall fescue (Festuca arundinacea). Though tall fescue can be controlled by ploughing and cropping, it poses a problem on those portions of the swamp containing timber. Rush control, incidentally, is also difficult on these areas, though attempted with spot spraying. Over the past few years Paspalum distichum has spread over the swamp country to an alarming extent and its control 
presents an urgent problem. It has even invaded the higher country, where it is found round gateways and water troughs.

The control of weeds in drains has always been a problem of the swamp country, entailing heavy manual work or the use of costly machinery. The most serious drain weeds of this district are Paspalum dilatatum, Paspalum distichum, Yorkshire fog, cocksfoot (Dactylis glomerata), reed sweet-grass (Glyceria maxima), and floating sweet-grass (Glyceria aquatica), watercress (Nastutium officinale), duckweed, (Lemna spp.), beggars tick (Bidens tripartitus), and sundry flat-leafed weeds. Of recent years higsly promising results have been obtained by spraying drains with a mixture of dalapon and amitrol at $20 \mathrm{lb}$ and $5 \mathrm{lb}$ per acre respectively.

Though water hyacinth (Eichhornia crassipes) has been found in drains in the Whakatane County, it has not so far been found elsewhere in the swamps of the Bay of Plenty.

The elimination of pussy willows (Salix caprea) has been one of the biggest single tasks in recent swamp development, and most of this work has been done mechanically. Unfortunately, large areas of grassed swamp land were allowed to revert to blackberry, rushes, pussy willow, and manuka, because of serious flooding of the Kaituna River near Te Puke, and the rehabilitation of this country is proving to be very costly.

\section{WEEDS OF CROPPING LAND}

Though cropping is not as common as it was 40 years ago, many farmers still grow an area of brassicas either for summer or winter feed. Soft turnips, swedes, and chou moellier are all grown throughout the Bay of Plenty. In addition considerable areas of maize are grown, mostly for grain

The prolific growth of annual weeds has always been a problem on cropping land, both on the higher country and on the swamp. The worst of these weeds are amaranthus (Amaranthus retroflexus) and willow weed (Polygonum persicaria), while weeds of less importance are spurrey (Spergula arvensis), fathen (Chenopodium spp.), and annual grasses such as crab grass (Digitaria sanguinalis), barnyard grass (Echinochloa crusgalli), and wild millet (Panicum milleaceum). In some years the prolific growth of these weeds has completely ruined a crop.

For several years it has been possible to control weeds in maize with amine 2,4-D, and the recent introduction of MCA (monochloracetate) offers great promise for the control of weeds in brassicas.

There are between two and three thousand acres of lucerne in the Bay, the most serious weeds of which are Poa annua, Indian doub, and browntop. Though some work has been done on the control of these weeds in lucerne with dalapon, results were not too promising, and there is scope for more investigation.

The establishment of new pasture after a crop is always risky, especially on older country, because of the risk of weed infestation. Excellent results have been obtained in the control of most of these weeds by the use of 2,4-DB or MCPB.

There are a large number of citrus and subtropical fruit orchards in the Bay of Plenty, particularly in the Tauranga County, but weed control on these areas has been greatly simplified since most of them have been sown down to grass between the trees. The regular mowing of this grass automatically helps to keep weeds under control.

There are also a number of nurseries and market gardens in the area, most of the latter specialising in either onions or asparagus. The most serious weeds of nurseries are oxalis (Oxalis cernua) and nut grass (Cyperus rotundus), and though some of the newer chemicals show promise in controlling these weeds, it cannot be said yet that they have been completely brought under control.

Weed control in asparagus has been based on the use of monuron at $4 \mathrm{lb}$ per acre as a pre-emergence treatment, while annual weeds in onions are controlled with sulphuric acid sprays. Even so a certain amount of mechanical and hand weeding is still usually required, and weed control in these crops is a laborious and costly operation. 


\section{CONCLUSION}

Since 1946 weed control in the Bay of Plenty has made great advances, largely because of the introduction of hormone weedkillers. Indeed, it is sometimes claimed that farmers have grown to rely too much on chemical weed control to the neglect of weed control by good husbandry and farm management. Be that as it may, no one can deny that the weed problem in the area is far less serious than it used to be.

And now, what of the future? I believe that there is still a place for intelligent farm management in weed control. The correct use of fertilisers, adequate subdivision, and stock management can all play their part in the fight against weeds. Similarly, there are great possibilities in the new rotary cutters, especially in the control of scrub weeds and gorse, and there are now weedicides available to control most of the weeds that remain a now weedicides available to control most of the weeds that remain a blackberry, Paspalum distichum, ragwort, docks, and Californian thistle, and means are available for controlling most of them.

Great strides have been taken in weed control in the Bay of Plenty over the past decade, but there is no room for complacency. We still have problem weeds for which satisfactory control measures are not available, and much more work will have to be done before it can be said that weeds are no longer a problem in the area. 